\title{
Stratigraphy and paleoecology of the Late Pliocene and Early Pleistocene in the open-cast mine Hambach (Lower Rhine Basin)
}

\author{
G. Heumann ${ }^{1} \&$ Th. Litt $^{1}$ \\ 1 Institut für Paläontologie der Universität Bonn, Nussallee 8, 53115 Bonn, Germany \\ e-mail: g.heumann@uni-bonn.de, t.litt@uni-bonn.de (corresponding author)
}

Manuscript received: December 2000; accepted: January 2002

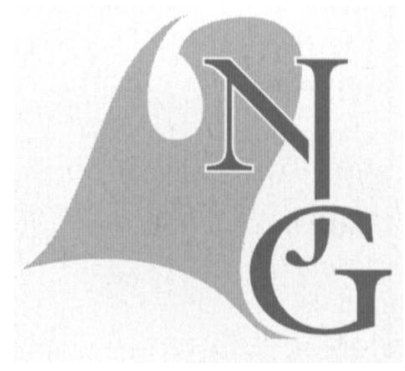

\begin{abstract}
More than 400 samples for paleobotanical and sedimentological investigations were collected from Late Pliocene and earliest Pleistocene beds in the open-cast lignite mine Hambach. They were analysed to obtain information about the paleoecology and paleoclimate of this time interval. The sedimentation type changed from a high-energy meandering fluvial system to floodplain, swamp and oxbow lake sedimentation. The typical Tertiary floral elements decreased with the onset of increasingly cooler climatic conditions and disappeared at the beginning of the Pleistocene to be substituted by a impoverished and coldadapted flora. These combined litho- and biostratigraphic investigations led to an improved and reproducible separation of Late Pliocene from Early Pleistocene deposits.
\end{abstract}

Keywords: Pliocene/Pleistocene boundary; Reuverian; Pretiglian; Germany; palynology; diaspores; palaeoecology; sedimentology

\section{Introduction}

During the last few years, great progress has been achieved in collecting litho- and biostratigraphic data for the Miocene section of the Lower Rhine Basin to reconstruct its sedimentological dynamics (Schäfer et al., 1996, 1997; Ashraf \& Mosbrugger, 1995; Huhn et al., 1997). However, our knowledge about the Pliocene and Pleistocene is comparably poor with respect to the integration of lithostratigraphy and biostratigraphy, at least in the German part of this region. Although Boenigk (1982) described distinctive changes in the petrography of the fluvial sediments during this period, we need an exact bio- and chronostratigraphic framework to understand the underlying processes in time and space.

Suitable sections for such an approach are available in the open-cast lignite mine Hambach which is locat- ed in the centre of the Erft Block. Generally, a lithostratigraphic subdivision established by Schneider $\&$ Thiele (1965) and adopted by the 'Rheinbraun' company (RB) is used in the Lower Rhine Basin. However, no biostratigraphic data links this lithostratigraphy to chronostratigraphy, apart from a vertebrate fauna of Early Villanyian age in stratum 11 (RB; Reuver clay; Mörs et al., 1998). Therefore we started detailed paleobotanical studies including pollen and plant macrofossil analyses several years ago.

When dealing with Pliocene/Pleistocene deposits, the controversial discussion about the Pliocene/Pleistocene boundary (PPB) figures prominently. The current PPB was defined at Vrica, in southern Italy, at the top of the Olduvai normal event at $1.77 \mathrm{Ma}$, and it was adopted by the IUGS in 1984 (Tab. 1). There are strong biostratigraphic, magnetostratigraphic and climatostratigraphic arguments against a PPB located 
at the top of the Olduvai event (Zagwijn, 1992; Suc et al., 1997; Partridge, 1997). As early as 1974, Zagwijn put forward evidence for the age of the earliest northern hemisphere glacial period (the Pretiglian in the Netherlands) post-dating at the Gauss-Matuyama boundary. Zagwijn $(1992,1998)$ is convinced that this climatic event, which can be correlated around the world (paleobotanical signal in Europe, oxygen isotope records from deep sea cores, onset of ice rafting in North Atlantic and loess formation in China), permits definition of the Quaternary relative to the Tertiary. There is a proposal by the INQUA Commission on Stratigraphy for lowering of the PPB to the vicinity of the Gauss/Matuyama paleomagnetic reversal within oxygen isotope Stage 104, approximately at $2.6 \mathrm{Ma}$ (Partridge, 1997). This boundary has the advantage of facilitating global stratigraphic correlation in both marine and terrestrial sequences.

The problem of the PPB has not been solved yet. Nevertheless, for a clear correlation within the Lower Rhine Basin which extends from the Netherlands to Germany, we use the stratigraphic terminology of Zagwijn who locates the PPB at the transition between Reuverian and Pretiglian which is above the Gauss/ Matuyama boundary between 2.5 and $2.6 \mathrm{Ma}$ (Zagwijn, 1998).

\section{Lithology}

The composite section at Hambach (Fig. 1) encompasses more than $50 \mathrm{~m}$ of sediments in five different sections in the open-cast mine. It starts with nearly 19 $\mathrm{m}$ of sand and gravel of the Kieseloolith Formation $(50.0 \mathrm{~m}-31.1 \mathrm{~m}$, stratum 10 of terminology used by $\mathrm{RB})$. The medium to coarse-grained, parallel- and cross-bedded, yellow-white sands were formed by a meandering fluvial system.

Between $38.2 \mathrm{~m}$ and $33.0 \mathrm{~m}$, the energy level of this river system strongly increased. The river cut channels into the beds underneath and filled them with parallel- to cross-bedded, medium- to coarsegrained gravel. In this gravel, thin sandy layers with Ophiomorpha and carbonised logs can be observed.

After the sudden stop of the fluvial sedimentation at $31.1 \mathrm{~m}$, it is replaced by a floodplain, swamp and oxbow sedimentation consisting of silt and finegrained sands intercalated with thin clay layers. These beds are part of stratum 11 (Reuver clay of $\mathrm{RB}$ ). The uppermost $2 \mathrm{~m}(26.4 \mathrm{~m}-24.4 \mathrm{~m})$ of these sediments, below a dark bed (middle part of stratum 11 of RB), are characterised by roots of trees, shrubs and herbs. The $1.40 \mathrm{~m}$ thick dark horizon is a brown coal seam located at $24.4 \mathrm{~m}-23.0 \mathrm{~m}$. Beds of silt and clay are intercalated. The sediments upwards to the next brown coal seam $(23.0 \mathrm{~m}-21.5 \mathrm{~m})$ are characterised by less calcareous silty and clayey beds, often with concretions. These beds are followed by a silty, fining upward section that shows many root traces at the top. According to Boenigk (1996), there is a remarkable change in the heavy mineral content in the upper part of stratum 11 (the transition between the socalled Kieseloolith Formation and Tegelen Formation; the latter is not the equivalent of the Tiglian in a chronostratigraphic sense, see Tab. 1).

The next lignite seam $(18.8 \mathrm{~m}-18.0 \mathrm{~m})$ belongs to the upper part of stratum 11 of RB. Often it is divided into a lower and an upper coal-bearing layer intercalated by a less organic-rich silt. According to the interpretation of this section by $\mathrm{RB}$, there is a hiatus between strata 11 and 13. This implies that stratum 12 (Pretiglian sands and gravel) is missing. This interpretation was not confirmed by our field observations (see below).

The next unit including the third significant coal seam $(18.0 \mathrm{~m}-11.0 \mathrm{~m})$, is interpreted by RB as stratum $13 \mathrm{~A}$, which is supposed to belong to the Tiglian complex. Silts of different grainsize, which are more calcareous with some concretions in the lower part, represent a continuous sedimentation in an oxbow lake. A rich mollusc fauna and sometimes a thin coal seam were observed. Near the top of this sequence, below the lignite seam, a remarkable horizon with a conspicuous green-blue colour was observed. Because of its colour, this bed in combination with the following lignite layer can be used as a marker horizon in the mine.

The section above stratum 13 A (after RB) consists of sand, silt and clay layers and intercalated thin coal bands $(11.0 \mathrm{~m}-0.0 \mathrm{~m})$. According to $\mathrm{RB}$ this sequence can be subdivided into several sub-strata of stratum 13 (13 B $-13 \mathrm{~F}$ ?) which probably belong to the Tiglian complex, too.

The entire sequence is unconformably overlain by the fluvial sediments of the 'Hauptterrasse' (strata $14-16$ of RB). It consists of yellow-brown, medium to coarse gravels. These sediments can be correlated with parts of the Kedichem Formation and the Sterksel Formation of the Dutch lithostratigraphy (Boenigk, 1996).

\section{Biostratigraphy}

Preliminary palynological investigations were carried out by Litt (1996) to improve the stratigraphic subdivision and to test the interpretation of $R B$ that there is a hiatus between stratum 11 (of the Reuverian age) and stratum 13 (of the Tiglian age). Random samples were taken from thin intercalated lignite layers in stra- 


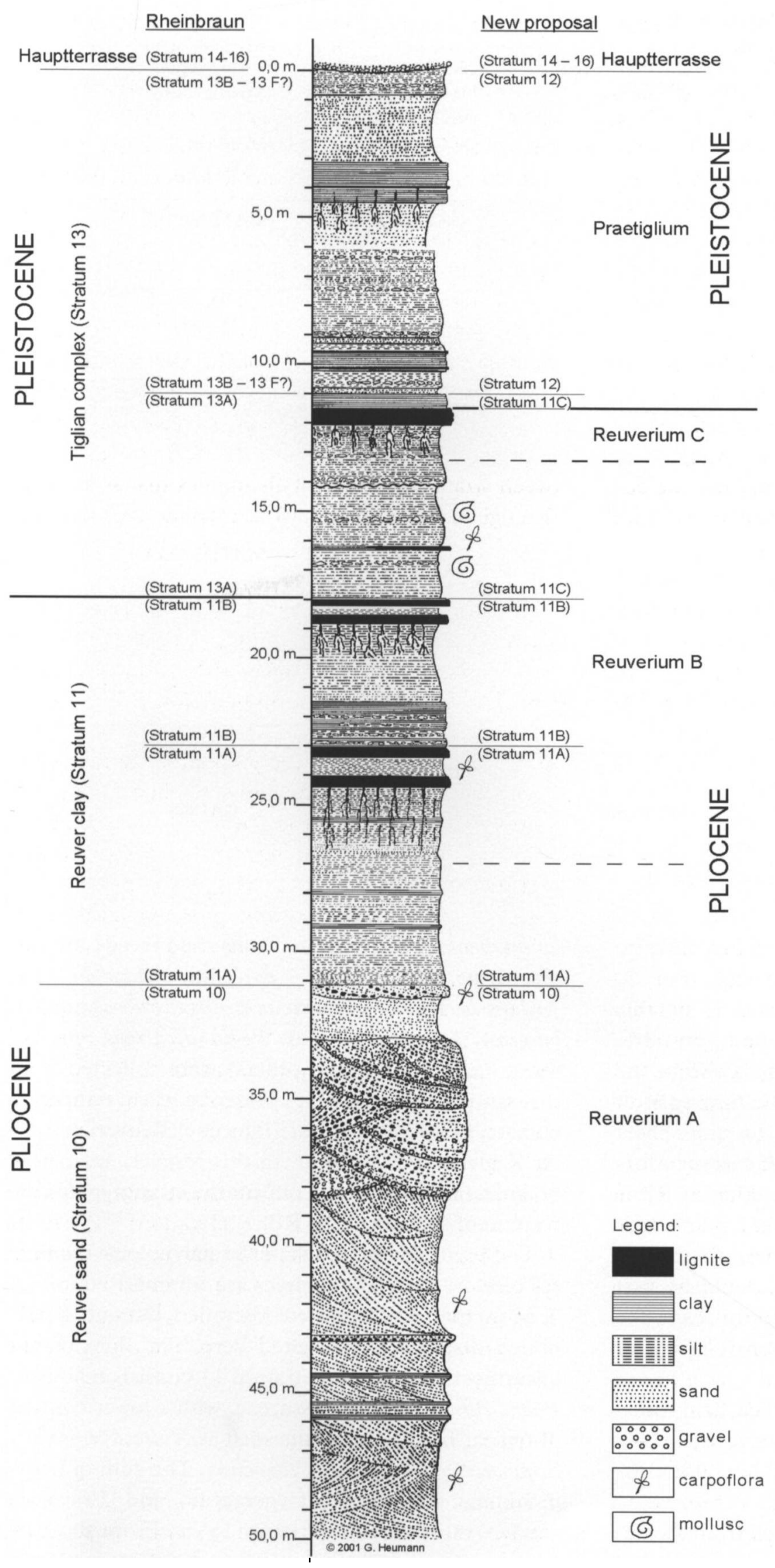

tum 11. From the palynological perspective, there can be no doubt that these horizons correlate with the Reuverian (as indicated by the occurrence of Sequoia,
Fig. 1. Composite section of the Plio-/Pleistocene beds in the open-cast mine Hambach (based on field observations in 1998/1999).
Sciadopitys, and Nyssa). A critical point was the biostratigraphic position of the significant lignite bed in stratum $13 \mathrm{~A}$ which can easily be used as a marker 
Tab. 1. Stratigraphy of the Late Pliocene/Early Pleistocene in the Lower Rhine Basin.

\begin{tabular}{|c|c|c|c|c|c|}
\hline $\begin{array}{l}\text { Lithostratigraphy } \\
\text { (in the Netherlands) } \\
\text { (Boenigk, 1982, } \\
\text { Tebbens et al., 1995, } \\
\text { Huisman \& Kiden, 1998) }\end{array}$ & $\begin{array}{c}\text { Biostratigraphy } \\
\text { Palynology } \\
\text { (in the Netherlands) } \\
\text { (Zagwijn, 1960, 1963) }\end{array}$ & $\begin{array}{c}\text { Pliocene/Pleistocene } \\
\text { Boundary } \\
\text { (INQUA-Proposal) }\end{array}$ & $\begin{array}{l}\text { Pliocene/Pleistocene } \\
\text { Boundary } \\
\text { (Vrica-Profil) } \\
\text { (IUGS, 1984) }\end{array}$ & $\begin{array}{c}\text { Magneto- } \\
\text { stratigraphy } \\
\text { (Shackelton et al., 1995) }\end{array}$ & (Ma) \\
\hline \multirow[t]{5}{*}{ Kedichem Formation } & Eburonian & & Pleistocene & MATUYAMA & 1.7 \\
\hline & & & & & 1.8 \\
\hline & & & & Olduvai & 1.9 \\
\hline & Tiglian & & & & 2.0 \\
\hline & & & & & 2.1 \\
\hline \multirow{6}{*}{ Tegelen Formation } & & Pleistocene & Pliocene & & 2.2 \\
\hline & & & & MATUYAMA & 2.3 \\
\hline & Praetiglian & & & & 2.4 \\
\hline & & & & & 2.5 \\
\hline & & & & & 2.6 \\
\hline & Reuverian C & & & & 2.7 \\
\hline \multirow{2}{*}{$\begin{array}{l}\text { Kieseloolite } \\
\text { Formation }\end{array}$} & Reuverian B & Pliocene & & GAUSS & 2.8 \\
\hline & & & & & 2.9 \\
\hline
\end{tabular}

horizon. A characteristic feature in the pollen diagram from this bed is the high amount of Osmunda (Fig. 2). The predominance of Pinus and Alnus is notable whereas thermophilous woody plants are very rare. The stratigraphic correlation of the beds within the Tiglian complex is difficult, because the time span of the deposition of the lignite seems to be quite short (without a characteristic succession). If this seam belongs to the Tiglian, then the interpretation of $\mathrm{RB}$ is insofar correct as this horizon is part of $13 \mathrm{~A}$ and confirms that there is really a hiatus between strata 11 and 13. An alternative interpretation would be that the lignite is of latest Reuverian age. In this case, the bed would have to be included in stratum 11 (Reuver clay) and there would be no hiatus.

To address this question, more detailed field investigations were undertaken to find longer sections covering the climatic fluctuations of the Late Pliocene and Early Pleistocene.

More than 400 samples were collected from the entire section described above for palaeobotanical analyses (pollen and plant macrofossils). Stratum 10 is characterised by a rich and a very diverse macroflora. Cones of different conifers (Pinus timleri, Picea latisquamosa), as well as fruits and seeds of angiosperms (Liquidambar europaea, Magnolia cor, Juglans bergomensis, Carya ventricosa, Pterocarya limburgense, Carpinus betulus, Fagus decurrens, Quercus robur, Vitis sylvestris, and others) were collected from this sand. These remains represent a warm temperate climate, typical for the Late Pliocene (Reuverian A after Zagwijn, 1960, 1963). In this respect, our paleobotanical investigations confirm the stratigraphic correlation of stratum 10 by $R B$.

The preliminary results of the palynological analyses of more than 270 samples are summarised in Fig. 3. More than 130 taxa were identified, but only a simplified diagram is presented here. The flora of the lowermost coal seam of stratum 11 consists mainly of Pinus, Alnus, and Cupressaceae, with a lower content of typical Tertiary elements such as Nyssa, Pterocarya, Sequoia, Sciadopitys, and Taxodium. The sum of herbs including Gramineae, Cyperaceae, and Ericaceae reaches values of up to 10 to $15 \%$. From the biostratigraphic point of view, it can be confirmed that this horizon belongs to the Reuverian B (sensu Zagwijn, 1960, 1963).

The next coal seam (at the top of stratum 11) is 


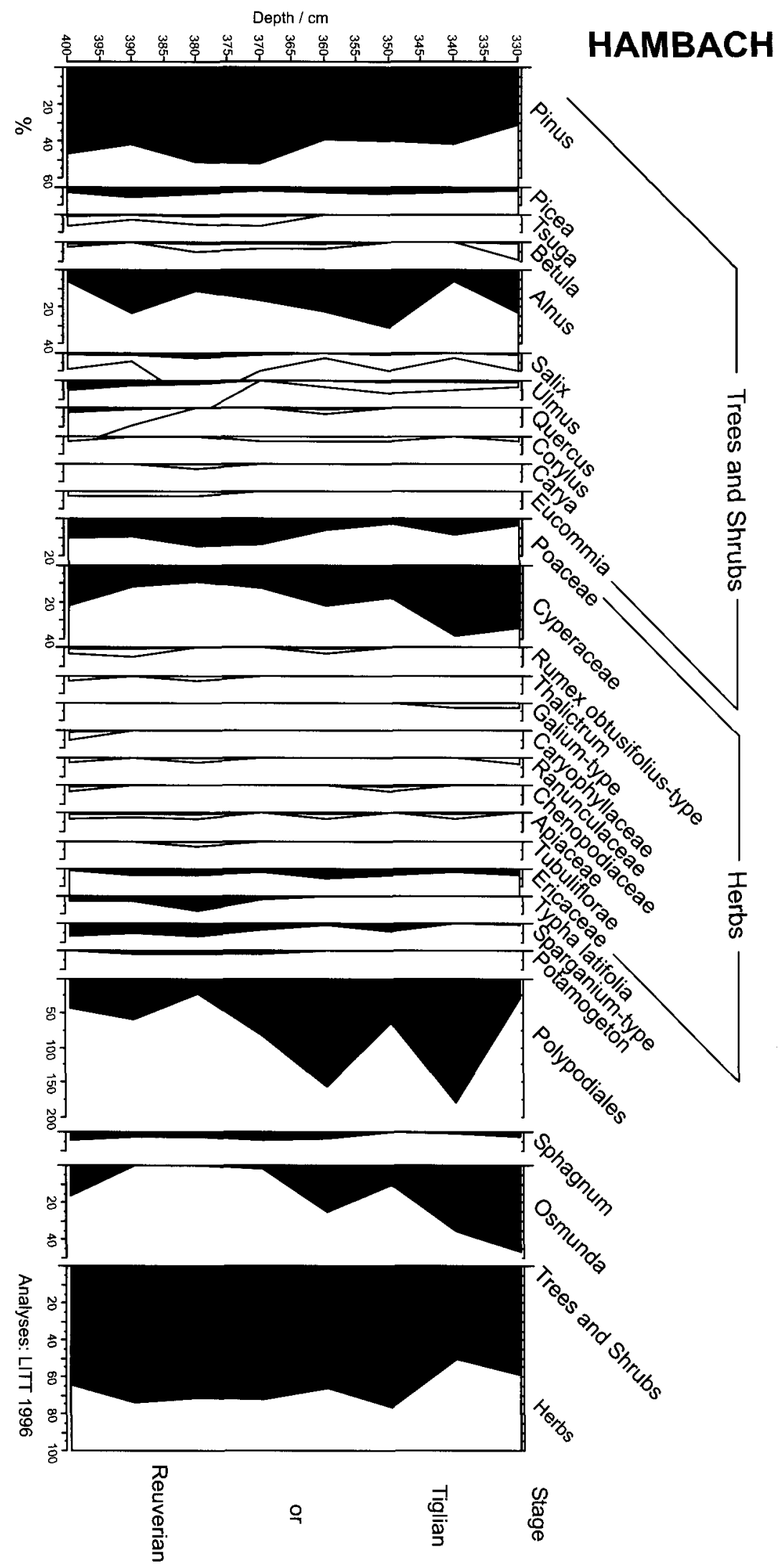

Fig. 2. Hambach, pollen diagram from the lignite horizon 13 A (after interpretation of Rheinbraun).

characterised by a comparably high content of Pinus and Alnus, but a reduced amount of Tertiary elements such as Cupressaceae, Nyssa, Pterocarya, Sequoia, Sciadopitys, and Taxodium. Gramineae and Ericaceae have nearly the same values as in the lower coal seam.
The palaeobotanical evidence strongly suggests a terminal Reuverian B age.

The pollen spectra of the third coal seam, interpreted as to be part of stratum $13 \mathrm{~A}$ by RB, show high values of Pinus and Alnus, some Salix, and extremely 


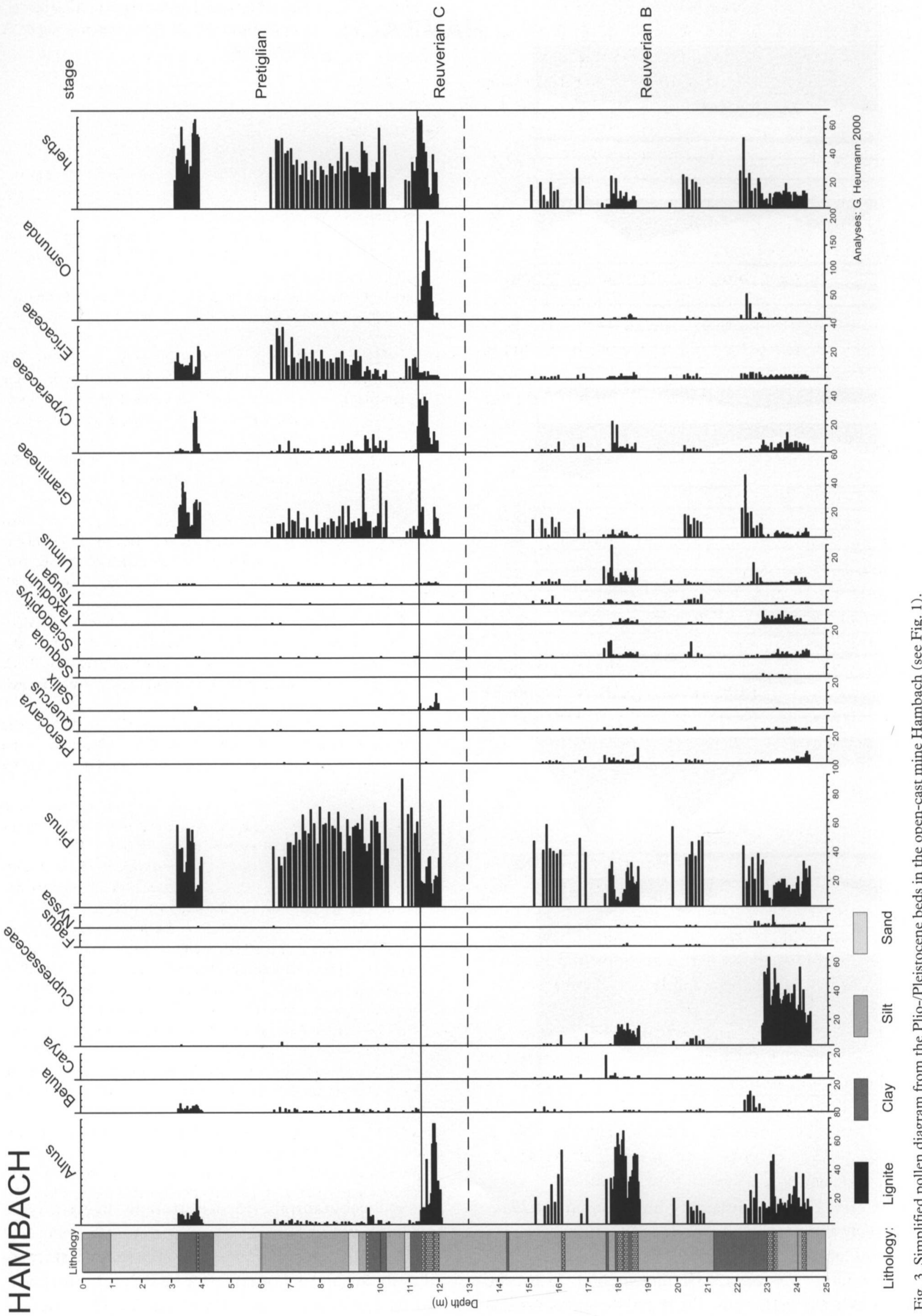


scarce Cupressaceae and Nyssa. There is no indication of Pterocarya, Sequoia, Sciadopitys, and Taxodium. The huge quantity of Gramineae, Ericaceae, and $\mathrm{Os}$ munda is a characteristic feature of this bed (see also Fig. 3). The herb values increase from $30 \%$ up to 70 $\%$. We correlate this horizon with the end of the Reuverian (Reuverian C) because no paleobotanical and no lithological hiatus can be observed between the second coal seam in stratum 11 and this one.

The vegetation development from the lowermost lignite seam upwards clearly shows a decrease of thermophilous elements reflecting the gradual cooling at the end of the Pliocene. Therefore, the third coal seam does not belong to the Tiglian (stratum 13) as previously interpreted by RB. It should be included into the stratum 11 .

The following samples (between $11.0 \mathrm{~m}-0.0 \mathrm{~m}$ of the section) show a very pauperised flora which is characterised by decreased values of Alnus and Pinus and the absence of thermophilous elements, whereas Gramineae and Ericaceae have increased. The herb values reach $70 \%$. This feature indicates cold climatic conditions which are typical for the Pretiglian (after Zagwijn, 1960).

Therefore we suggest that this unit $(11.0-0.0 \mathrm{~m})$ is equivalent to stratum 12. In contrast to previous interpretations, the palynological results clearly show the presence of deposits with a Pretiglian age. As a consequence, the PPB (sensu INQUA proposal) should be drawn at the top of the uppermost significant lignite seam of Reuverian C age.

\section{Conclusions}

1. Lithological data alone, as applied in previous studies cannot solve the stratigraphic problems in the open-cast mine Hambach and adjacent regions of the Lower Rhine Basin.

2. Combined litho- and biostratigraphic investigations in this open pit led to an improved subdivision of Upper Pliocene and Lower Pleistocene deposits.

3. There is strong biostratigraphic evidence to modify the stratigraphic scheme currently used by the Rheinbraun Company.

4. The Pliocene/Pleistocene boundary at the Reuverian/Pretiglian transition is clearly reproducible in Hambach and can be used as a 'golden spike' for correlations in the Lower Rhine Basin.

\section{Acknowledgement}

This study was supported by the Deutsche Forschungsgemeinschaft (SFB 350, Project C3,
Schäfer \& Litt). We thank the Rheinbraun Company for fruitful cooperation. Karl-Ernst Behre (Wilhelmshaven) and Hans Kerp (Münster) carefully read the manuscript.

\section{References}

Ashraf, A.R. \& Mosbrugger, V., 1995. Palynologie und Palynostratigraphie des Neogens der Niederrheinischen Bucht. Teil 1: Sporen. Palaeontographica B 235: 61-173.

Boenigk, W., 1982. Der Einfluß des Rheingraben-Systems auf die Flußgeschichte des Rheins. Zeitschrift für Geomorphologie N. F. Supplement 49: 167-175.

Boenigk, W., 1996. Excursion to the open-cast mine "Hambach". In: INQUA-SEQS Symposium 16-21. June 1996, Kerkrade. Excursion-Guide: $10 \mathrm{pp}$

Huhn, B., Utescher, T., Ashraf, A. R. \& Mosbrugger, V., 1997. The peat-forming vegetation in the Middle Miocene Lower Rhine Embayment, an analysis based on palynological data. Mededelingen Nederlands Instituut voor Toegepaste Geowetenschappen TNO 58: 211-218.

Litt, Th., 1996. Excursion to the open-cast mine "Hambach“. In: INQUA-SEQS Symposium 16.-21. June 1996, Kerkrade. Excursion-Guide: 5 pp.

Mörs, Th., von Koenigswald, W. \& von der Hocht, F., 1998. Rodents, (Mammalia) from the Late Pliocene Reuver Clay of Hambach, Lower Rhine Embayment, Germany). Mededelingen Nederlands Instituut voor Toegepaste Geowetenschappen TNO 60: 135-159.

Partridge, T.C., 1997. Reassessment of the position of the PlioPleistocene boundary: Is there a case for lowering it to the Gauss-Matuyama palaeomagnetic reversal? In: Partridge, T. C. (ed.): The Plio-Pleistocene Boundary. Quaternary International 40(1): 5-10.

Schäfer, A., Hilger, D., Gross, G. \& von der Hocht, F., 1996. Cyclic sedimentation in Tertiary Lower-Rhine Basin (Germany) - the 'Liegendrücken' of the brown-coal open-cast Fortuna mine. Sedimentary Geology 103: 229-247.

Schäfer, A., Utescher, T. \& von der Hocht, F., 1997. Klastische Sedimentsysteme im Tertiär der Niederrheinschen Bucht. Terra Nostra, Schriften d. A.-Wegener-Stiftung 97/3: 68-113.

Schneider, H. \& Thiele, S., 1965. Geohydrologie des Erftgebietes. Ministerium für Ernährung, Landwirtschaft und Forsten des Landes Nordrhein-Westfalen (Düsseldorf): $185 \mathrm{pp}$.

Suc, J.-P., Bertini, A., Leroy, S.A.G. \& Suballyova, D., 1997. Towards the lowering of the Pliocene/Pleistocene boundary to the Gauss-Matuyama Reversal. In: Partridge, T. C. (ed.): The PlioPleistocene Boundary. Quaternary International 40(1): 37-42.

Zagwijn, W.H., 1960. Aspects of the Pliocene and Early Pleistocene Vegetation in the Netherlands. Mededelingen van de Geologische Stichting Serie C-III-1 5: 1-78.

Zagwijn, W.H., 1963. Pollen-analytic investigations in the Tiglian of the Netherlands. Mededelingen van de Geologische Stichting Nieuwe Serie 16: 49-71.

Zagwijn, W.H., 1974. The Pliocene-Pleistocene boundary in western and southern Europe. Boreas 3: 75-97.

Zagwijn, W.H., 1992. The beginning of the ice age in Europe and its major subdivisions. Quaternary Science Review 11: 583-591.

Zagwijn, W.H., 1998. Borders and boundaries: a century of stratigraphical research in the Tegelen - Reuver area of Limburg (The Netherlands). Mededelingen Nederlands Instituut voor Toegepaste Geowetenschappen TNO 60: 19-34. 